\title{
Kisebbségi identitáskonstrukciók a kettős magyar állampolgárság által
}

\section{Bevezetö}

\section{$\mathrm{T}$} anulmányunkban a magyar állampolgársági törvény által lehetővé vált, a külhoni magyarok által könnyített honosítási eljárásban megszerezhető állampolgársághoz való viszonyulások elemzésére teszünk kísérletet egy pilot-jellegü kvalitatív vizsgálat alapján. Röviden, arról szeretnénk képet kapni, hogy ez az állampolgárság (amelyet a későbbiekben szinonimaként „új állampolgársággal” vagy „kettős (magyar) állampolgársággal” is illetünk), hogyan hat ki arra a célcsoportra, amelynek tagjai egy másik országban szociológiai, demográfiai kisebbségi feltételek mellett élnek. Mivel fókuszcsoportos beszélgetésekre épülő vizsgálatról lesz szó, valójában azt kíséreljük meg elemezni, hogy az érintett szereplők diszkurzíve hogyan viszonyulnak a magyar állam részéről felkínált lehetőséghez, valamint azt, hogy az állampolgársághoz kapcsolódó identitás hogyan kapcsolódik a kisebbségben élők sajátos identitás-állapotához, a létező kötődéseikhez. Központi kérdésünk tehát egyrészt az, hogy a kisebbségi etnocentrizmus hogyan kapcsolódik a magyar állampolgárság és útlevél megszerzéséhez? Másodsorban pedig arra is választ szeretnénk kapni, milyen tényezők hatnak a magyarországi, illetve a saját társadalom irányába mutató kötődések szintjén, és mindebben az „új” állampolgárságból levezethető identitáselemek hogyan jelennek meg. Ahhoz, hogy erre válaszokat kapjunk, először körüljárjuk a többes állampolgárság, majd pedig a

\footnotetext{
* Papp Z. Attila, MTA TK Kisebbségkutató Intézet, Budapest, tudományos főmunkatárs, pappz.attila@tk.mta.hu
} 
témánk szempontjából fontosnak tartott kisebbségi „lét” szociológiai és identitásbeli vetületeit, lehetséges értelmezéseit.

\section{A többes állampolgárság néhány szociológiai vonatkozása}

Az állampolgárság hagyományos értelemben egy ország és egy személy közötti „bijektív”, azaz olyan kapcsolat, amely azt feltételezi, hogy egy személynek egy és csakis egy állampolgársága lehet. Az állampolgárság által az egyén és az állam között jogi, de identitásbeli és érzelmi szimbiózis is létezik, hiszen kölcsönösen egymásra utaltak a különféle jogok és kötelezettségek által. E koncepció sokáig tartotta magát, és ez köszönt vissza a jogi szakirodalomban elhíresült Nottebohm-ügyben is, amikor a Nemzetközi Bíróság kimondta, hogy az állampolgárság „olyan jogi kötelék, amelynek alapja egy kötődés, mint társadalmi tény, a létezés, az érdek és érzelem tényleges kapcsolata, a kölcsönös jogok és kötelezettségek fennállásával együtt". A bíróság indoklása szerint az állampolgárság megszerzése az ember életében ritkán előforduló „komoly” dolog, ami által korábbi kötelékei megszünnek és újak jönnek létre, és mindez az egyéni sorsokra hosszú távon is kihat. ${ }^{1}$

Az állampolgárságot és honosítást, illetve az ezt fenntartani hivatott nemzeti identitást gyakran a házasság intézményéhez hasonlították, mondván, hogy itt kizáró jellegü, hosszú távú kapcsolatok kialakításáról, megszerzéséről és fenntartásáról van szó. Az ettől való eltérés pedig ritkának, tiltandónak számított, csakúgy, mint a nyugati keresztény világban a bigámia. Nem véletlen, hogy a többes állampolgárságra ráhúzott, leggyakrabban előforduló metafora a bi- vagy poligámia, hiszen ezek is olyan kapcsolatokként tételeződnek, ahol a lojalitás megkérdőjeleződhet. Az állampolgárság a klasszikus értelmezésben nem szüntethető meg, nem cserélhető le,

\footnotetext{
${ }^{1}$ „Naturalization is not a matter to be taken lightly. To seek and to obtain it is not something that happens frequently in the life of a human being. It involves his breaking of a bond of allegiance and his establishment of a new bond of allegiance. It may have far-reaching consequences and involve profound changes in the destiny of the individual who obtains it." Ld. International Court of Justice, Report of Judgement Advisory Opinions and Orders, NOTTEBOHM CASE (Lichenstein vs. Guatemala), Second Phase, Judgement of April 6th, 1955, p. 24.
} 
akárcsak a házasság sem volt az évszázadokon keresztül, és egyes egyházak szerint ma sem az. ${ }^{2}$

Az állampolgárságot „komolyan” vevő értelmezése azonban a globális világ elismerésével és tényként való kezelésével sokat változott. A globalizációhoz kapcsolódó életviteli gyakorlatok elterjedésével, a nemzetállami keretek kizárólagosságának csorbulásával tudatosult, hogy az identitás nem egy és örök, hanem kontextuális, aktuális helyzetek által meghatározott jellemzőkkel bír. A kettős és többes állampolgárság fogalmai így leggyakrabban a migráció, illetve a globalizáció kihívásaival kapcsolatosan kerülnek tárgyalásra, hiszen e kitágult világban a jus sanguinis és a jus soli, azaz a vérségi és területi elvek összemosódása még inkább lehetővé

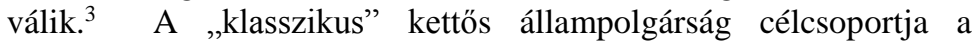
bevándorlók, és e kontextusban az állampolgárság megszerzése a társadalmi, pontosabban a befogadó nemzetállamon belüli integráció eszközeként tételeződik. A globalizáció témakörében tárgyalt többes állampolgárság azonban már mintha veszített volna „,nemzeti súlyából”, „komolyságából”, és az állampolgárság jobbára mint egy lehetséges tagság jelenik meg. Míg a klasszikus állampolgárság metaforája a ,család” volt, addig a többes állampolgárságot a klubtagsághoz hasonlíthatjuk, amelyet egyéni döntés által szerezhetünk meg, avagy mondhatunk le róla. ${ }^{4}$ Ugyanakkor egy egyén egyszerre több klubnak is lehet a tagja, és mindenik szervezetben más-más identitását aktualizálhatja. Kérdés, persze, hogy a különféle kontextusok által meghatározott identitások között feszülnek-e ellentétek, és ha igen, e belső kognitív disszonanciákat hogyan kezeli az egyén, avagy azok a közösségek, ahova tartozik.

Mindez azt is jelenti, hogy az állampolgárság ma már egyfajta rugalmassággal jellemezhető, az állampolgárság és az ehhez gyakran

\footnotetext{
${ }^{2}$ Aleinikoff, T. Alexander - Klusmeyer, Douglas: Plural Nationality: Facing the Future in a Migratory World. In: Weiner, Myron - Russel Stanton , Sharon (szerk.): Demography and National Security. New York, Berghahn, 2001. Martin, David A. - Aleinikoff, T. Alexander: Double Ties. In: Foreign Policy, 2002. 133:80-81. Pogonyi Szabolcs: Dual citizenship and sovereignity. In: Nationalities Paper. 2011, Vol. 39., 5. 685-704. Spiro, Peter J.: Dual citizenship as human right. I In: Con, 2010, 1. 114.

${ }^{3}$ E két elv összejátszása eredményeképpen jött létre a kettős állampolgárság. Spiro: Dual..., 2010, i.m., 113.

${ }^{4}$ Spiro: Dual..., 2010, i.m., 119.
} 
pragmatikusan társított útlevél is flexibilissé válik, az állampolgárság mondhatni elveszíti „nemzeti komolyságát”. Aihwa Ong szerint az útlevélben megtestesülő nemzeti jegyek globális feltételek közepette fokozatosan átadják a helyüket egy másfajta hamis használatnak: az állampolgárság és az útlevél közé nem tehetünk egyenlöségjelet, azaz az útlevél egyre inkább nem a nemzeti hovatartozást fejezi ki. ${ }^{5}$ Amint az tanulmányunk későbbi részében is kiderül, a flexible citizenship (passport) jelensége egyértelmüen érvényes a határon túli magyarok esetében is, hiszen az új magyar útlevél is lehetővé teszi azt a játékosságot, amelynek következtében az állampolgárságok vállalása is kontextuálisan meghatározott. Ugyanakkor alkalmazható azokra a többségiekre (ukránokra, szerbekre, románokra) is, akik legalábbis az elbeszélések szintjén- gyanúsnak mondható módon ${ }^{6}$ szereztek magyar állampolgárságot, az ő esetükben is az új állampolgárság pragmatikus, flexibilis módon egyéni életstratégiákba ágyazódik. ${ }^{7}$

Az EU-ban is megállapítható, hogy az állampolgárság egyre inkább elveszíti nemzeti, etnikai jellegét, és jobbára egy politikai közösség identitását bizonyító kötelékké vált. ${ }^{8} \mathrm{Az}$ állampolgárság ugyan a politikai tagság kifejezésére szolgál, azonban ehhez a „hovatartozás”, a „gyökerezettség élménye” szükséges, mely lehetővé teszi a ,generációk közötti összekapcsolódás érzését, és ezáltal egyfajta történelmi transzcendenciát és folyamatosságot" is. ${ }^{9}$

5 Ong, Aihwa: Flexible Citizenship. The Cultural Logics of Transnationality. Duke University Press, 1999. Fox, Jonathan: Unpacking „Transnational Citizenship". In: Annual Review of Political Science, 2005, 8.171-201.

6 Ld. az erre specializálódott ukrán és orosz nyelvü honlapokat is, pl. http://vengrija.com.ual.

L. még:

http://index.hu/gazdasag/2014/09/16/magyar_nyelven_szavaltak_szep_magyar_s zoveget/?utm_source $=$ facebook\&utm_medium $=$ share\&utm_campaign=index

${ }^{7}$ Convay, Dennis - Potter, Robert B. - Bernard, Godfrey St.: Dual citizenship or dual identity? Does transnationalism' supplant 'nationalism' among returning Trinidadians? In: Global Networks. 2008, 4. 373-397.

${ }^{8}$ Szabó Marcel: A többes állampolgárság - új nemzetközi és uniós perspektívák felé? In: Állam és Jogtudomány. 2013, 1-2. 143.

${ }^{9}$ Rubio-Marin, Ruth: Transnational Politics and the Democratic Nation-State: Normative Challenges of Expatriate Voting and nationality Retention of Emigrants. In: New York University Law Review. 2006, 81. 136. Idézi Szabó Marcel: A többes állampolgárság... 2013, i.m. 143. 
Csakhogy mindez viszonylagossá válik a többes identitással megáldott többes állampolgárság vállalása során, és felveti azt a kérdést, hogyan lehet lojálisnak lenni több állam irányába. A kérdésre többféle válasz is adható.

Először is könnyen belátható, hogy a többféle állampolgárság nem egyfajta súllyal esik latba az egyéni életvitel során, hiszen használati vagy érzelmi értéke más-más jellegü. Ez érvényes a migránsok esetében, illetve a nemzeti kisebbségek esetében is. A svéd kettős állampolgárság elfogadásának előzményeit elemezve Gustafson például arra is felhívja figyelmet, hogy a kettős állampolgárság intézménye ugyan kikezdi a „hagyományos” állampolgárság-koncepciók homogenizáló jellegét, de ugyanakkor egyfajta individualizációt is feltételez, mivel az új állampolgárság egyénenként szerezhető meg. A migránsok esetében éles különbséget tehetünk a „küldő” és a „befogadó” országok állampolgárságai között: az előbbi az „óhaza”, a gyökerek továbbélésének mítoszát hordozzák, az utóbbi pedig praktikus-jogi okokból válik fontossá a társadalmi integráció során. ${ }^{10}$ Ezért a bevándorlók esetében nagy érzelmi teher volna, ha az új állampolgárságot csak úgy vehetnék fel, ha a korábbi állampolgárságukról és az ehhez kapcsolódó érzelmi kötelékeikröl le kellene mondaniuk. Ugyanez elmondható a nem bevándorló, öshonos nemzeti kisebbségeket érintő potenciális kettős állampolgárokról is, hiszen az ő esetükben sem feltételezhetjük, hogy objektív és szubjektív szinten egyforma lenne az állampolgárság haszna vagy megítélése. A többféle állampolgárság kiegészíti egymást, és szubjektív szinten az egyének választanak ezek között, avagy valamilyen logika alapján hierarchikus viszonyba állítják: megkülönböztetik az elsődleges és a másodlagos állampolgárságokat. Ahogy Spiro fogalmazott, „egyik állampolgárság mindig édesebb, mint a másik". ${ }^{11}$ A két állampolgárság tehát két identitást hordoz(hat), de ezáltal nem bomlik meg az egyén pszichológiai egyensúlya: valamelyik ugyan kedvesebb - de ez valószínüleg kontextuálisan meghatározott. A

\footnotetext{
${ }^{10}$ Gustafson, Per: Globalisation, multiculturalism and individualism: the Swedish debate on dual citizenship. In: Journal of Ethnic and Migration Studies. 2002, 3. 474.

11, ,...plural citizenship will almost always involve one citizenship that is dearer than the other.” Ld. Spiro, Peter J.: Dual citizenship ..., 2010, i.m., 114.
} 
„második” állampolgár-identitás a migránsok esetében komfortérzetből vagy politikai-társadalmi hasznosságból lesz fontos, a nemzeti kisebbségek esetében pedig ezt a funkciót az elsődleges, lakóhelyhez és területiséghez kötött állampolgárság fogja betölteni.

Ha elfogadjuk a különféle állampolgárságok más-más gyakorlati értékét, akkor további dimenziók mentén is csoportosíthatjuk. Az érzelmi és praktikus okok mellett beláthatjuk azt is, hogy létezhet egy társadalmi és egy politikai állampolgárság is: előbbi a kettős állampolgárok mindennapi interakcióiban tetten érhető identitásával kapcsolatos, utóbbi pedig a politikai (különösen szavazati) jogok meglétével függ össze. A mindennapi interakciókban a kettős állampolgárok megítélése másképpen történik megengedö jogszabállyal, illetve tiltó jogi környezet közepette. Ha a jogszabály formálisan megengedő a kettős állampolgársággal szemben, az nem jelenti azt, hogy ne lépnének életbe olyan társadalmi mechanizmusok, amelyek megakadályozzák vagy diszkurzíve tiltják a kettős állampolgárságot. Ha egy ország jogszabálya formálisan is tiltja az állampolgárságot, a kettős állampolgárok - e tekintetben - rejtőzködni kényszerülnek a társadalmi interakciók során, és ez független attól, hogy élnek-e politikai jogaikkal vagy sem.

A többes állampolgárság ma már egyre elterjedtebb kategóriáján belül négyféle állampolgárságot különítenek el az egyes szerzők: a posztnacionális, a transznacionális, a globális és a szupranacionális állampolgárságot. Posztnacionális keretben az identitás jelentősége csökken, és az állampolgársággal nem rendelkezők kvázi tagsági jogaira is utal. A transznacionális állampolgárság klasszikusan a több állam által elismert állampolgárságokat, a globális állampolgárság pedig a nemzetit meghaladó politikai szervezetekhez való kötődéseket jelenti, míg a szupranacionális legjobb kifejezője az európai uniós állampolgárság. ${ }^{12}$

$\mathrm{Az}$ állampolgárság meghatározása az állam joga, és céljai függvényében definiálhatja ezek jellegét, dönthet arról is, hogy kíván-e első- és másodrendű állampolgárokat saját jogi keretei között fenntartani. Az állampolgárság meghatározása során érvényesített jogi kritériumok alapján szintén többféle többes állampolgárságot

${ }^{12}$ Szabó Marcel: A többes állampolgárság..., 2013, i.m. 143. 
határozhatunk meg. Bauböck szerint például háromféle transznacionális állampolgár létezik: a két vagy több ország által is elismert többes állampolgárok mellett megkülönböztet két egymással ellentétes kategóriát is: az ún. denizenshipeket, illetve az ethnizenshipeket. A denizenship azokra a személyekre vonatkozik, akik tartósan egy másik országban élnek, anélkül, hogy ott állampolgárságot igényelnének, az utóbbi pedig a nemzeti kisebbségek és anyaország állampolgárság-jellegü kapcsolatára utal. Az ethnizenship tehát olyan állampolgárságot jelent, amelyet egy ország területén életvitelszerüen nem élö, egy másik állampolgárságot bíró személy etnikai (nyelvi, kulturális, származási) alapon megszerezhet.

A kettős/többes állampolgárság elterjedése a globális feltételek közepette egyre inkább elfogadott, ahogyan arról Bloemraad fogalmazott, ti. hogy a kettős állampolgárság a transznacionalizmus oka és következménye is, mivel egyrészt elösegíti azt, másrészt pedig többes identitásokat vagy több országhoz kapcsolódó kötődéséket is kitermel. ${ }^{13}$ Tudatában lévén annak, hogy egyéni szinten a többes állampolgárság előnyökkel is járhat, mégis fel kell tennünk a kérdést, hogy milyen kockázatokat rejteget a többes állampolgárság. Ez azért is érdekes kérdés, mert bármilyen állampolgárság egyszerre hordozza a kizárás és befogadás mozzanatait, amelyet az érintett országok többek között a jogok és kötelezettségek rendszerén keresztül érvényesíthetnek. A kettős állampolgárság mellett egyéni jogként érvelö Spiro is azt állítja, hogy ez ellen még liberális perspektívából is két nagy ellenérv hozható fel. A kettős állampolgárság egyrészt egyenlőtlenségeket termel, mivel mindenkinek nem adatik meg ennek birtoklása, másrészt pedig aláaknázza a polgári, társadalmi szolidaritást. Míg az elöbbi ellenérvet könnyen visszaveri, azt állítva, hogy a kettős állampolgárság megtagadása is éppúgy egyenlőtlenséget szül azok számára, akik egy más országban élnek, ${ }^{14}$ addig a szolidaritás elleni érvet végül „érzelmi” szinten tudja megválaszolni. A szolidaritás klasszikus formái, mint a sorkatonaság, az adófizetés szabályozható

\footnotetext{
${ }^{13}$ Bloemraad, Irene: Who claims dual citizenship? The limits of postnationalism, the possibilities of transnationalism, and the persistence of traditional citizenship. In: International Migration Review. 2004, 38 (2), 394.

${ }^{14}$ Spiro, Peter J.: Dual citizenship ..., 2010, i.m., 125.
} 
a kettős állampolgárok esetében, ám az állampolgárságból levezethető identitások szintjén már vélhetően különbségek állapíthatók meg a polgárok között. Ahogy az elöbbiekben már jeleztük, ö azt állítja, hogy nem egyformán fontosak az állampolgárságok, amely azonban véleményünk szerint további egyenlötlenségeket szülhet: a rezidens országhoz így lesznek, akik érzelmileg és instrumentálisan is kötődnek, míg lesznek olyanok, akik „csak” praktikus okokból. Az „óhaza” (kin-state) viszonylatában is eltérések jelentkeznek, hiszen lesznek olyanok, akik ehhez csak érzelmileg kötődnek. Az állampolgársághoz kapcsolódó politikai jogok kapcsán Bauböck megjegyzi, hogy az ethnizenship, azaz a nemzeti kisebbségek kettős állampolgársága esetében nem ajánlatos az anyaországi szavazójog kiterjesztése, hiszen ez által a saját országon belül, a „szülőföldön” a politikai képviselet csorbulhat. Ez hosszú távon azt eredményezheti, hogy a politikai képviseletet az anyaország, azaz egy másik ország látja el, avagy arra ruházzák át. Ez pedig azt is jelentheti, hogy a nemzeti kisebbségeknek diaszpóraként, azaz az „óhaza” és a „visszatérés” mítoszát hordozó közösségként kellene újradefiniálniuk önmagukat. ${ }^{15}$

E kommunitáriusnak nevezhető érvelés köszön vissza szinte szó szerint Salat Leventénél, aki azt állítja, hogy ,a nemzetpolitika jelenlegi föiránya az elszakadt nemzetrészeket az önálló politikai közösségként való elfogadtatás érdekében folytatott küzdelem pályájáról átállította az intézményesített diaszpóra pályájára". ${ }^{16}$

\section{Szociológiai szempontok a magyar kettős állampolgárság vonatkozásában}

A magyar kettős állampolgárság 2010-es intézményesülését valójában nem előzte meg nyilvános szakmai vita, az elemzések így

\footnotetext{
15 Bauböck, Rainer: Stakeholder Citizenship and Transnational Political Participation: A Normative Evaluation of External Voting. In: Fordham Law Review. 2007, 5, 2396-2447. (a tanulmány rövidített magyar változatát lásd jelen lapszámunkban - a szerk. megj.)

${ }^{16}$ Salat Levente: A könnyített honosítás látható és várható következményeiröl. Válaszok a Magyar Kisebbség kérdéseire. In: Magyar Kisebbség, 2013, 3-4, 231.
} 
inkább post facto történhetnek. ${ }^{17}$ Szocio-demográfiai jellemzők mentén részletezett naprakész hivatalos adatokkal sem rendelkezünk. Ritka kivételnek számított az, hogy a 2013 novemberében az MTA TK Kisebbségkutató Intézet Állampolgárság, honosítás, integráció 20 éves az állampolgársági törvény c. konferenciáján néhány hivatalos adatot is megtudhattunk a kérelmezők számáról, időbeni alakulásáról, területi és korcsoport szerinti megoszlásáról. ${ }^{18}$

A témában kvantitatív elemzések - a Kolozsvári Kisebbségkutató Intézetét leszámítva - nem igazán készültek. Saját kvalitatív kutatásunk perspektívájából a kettős állampolgárság értelmezéséről két szociológiai ihletettségü elemzést említhetünk meg. Az egyik inkább a makropolitikai és a klasszifikációs küzdelem kontextusába helyezi, a másik pedig egy sajátos diszkurzív szinten akarja megragadni. A makro-megközelítésü eszmefuttatás Kiss Tamás müve, ${ }^{19}$ aki elöbb két komplementer keretben is (történeti, migrációpolitikai viszonylatban) tálalja e kérdéskört, majd elveti ezeket, mondván, hogy az állampolgárság-politika nagyobb kontextust feltételez, mivel a határon túli magyarok migrációs célcsoportja elsősorban nem Magyarország, ezért az az elképzelés (lásd Melegh Attila) miszerint a külhoni magyarok pótolják a magyar népességcsökkenést, igencsak kérdésessé válik. Kiss végül az állampolgárságot - Bourdieu és Brubaker sémái alapján klasszifikációs küzdelemként értelmezi, amelyben a magyar nemzet mint olyan is definiálódik. Ebben a kontextusban az állampolgárság a nemzet definíciója iránti eszközként jelenik meg, és azt állítja, így megragadható a kisebbségi társadalom integrációs perspektívája. Ô

${ }^{17}$ Ilyennek tekinthetjük a Magyar Kisebbség tematikus 2013/3-4-es lapszámát, ahol egy körkérdés keretében szakértők, aktív kisebbségi politikusok és kormányzati szereplők is hozzászóltak a kettős állampolgárság kérdéséhez. Ezek részéletes ismertetésétől eltekintek, de azt mindenképpen jelezném, hogy a vajdasági, kárpátaljai és erdélyi kisebbségi politikusok a magyar állampolgárság kiterjesztésének pozitív fogadtatása mellett egyaránt szóvá teszik azt, hogy ez a kisebbségvédelem és a közösségi integráció és autonómiatörekvések szempontjából nem a legsikeresebb eszköz.

${ }^{18}$ Ld. Bodnár Gergely előadásának prezentációját itt:

http://kisebbsegkutato.tk.mta.hu/hirek/2013/12/allampolgarsag-honositasintegracioletolt

${ }^{19}$ Kiss Tamás: Nemzetdiskurzusok hálójában. Az állampolgárságpolitika, mint a magyar nemzetre vonatkozó klasszifikációs küzdelem epizódja és eszköze. In: Magyar Kisebbség. 2013, 3-4, 7-95. 
amellett érvel, hogy Budapest szerepe megerősödik, ezért a saját társadalom projektje megbukik vagy meg fog bukni. Ezzel párhuzamosan számára az a kérdés, hogy az erdélyi magyarok identifikációja hogyan alakul, ezért külön foglalkozik a többségi nemzettel vagy nemzethez való viszonnyal. E logikában úgy érzi/méri, a magyar állampolgárság megszerzése által a többségi (politikai) nemzethez való tartozás mértéke csökken. Paradox módon ezen állítását általa módszertanilag kritizált adatsorokkal kívánja alátámasztani. ${ }^{20}$ Ebben az írásban azonban feltünő a nemzet

${ }^{20}$ Kiss folyóirat-terjedelemhez képest meglehetősen terjengős cikkében a Kárpát Panelt kritizálva szó szerint belebonyolódik a nemzet fogalmába. (Noha a szerző nem jelzi, kritikája gyakran szó szerint is egy korábbi, társszerzővel közösen jegyzett müben már megjelent: Kiss Tamás - Barna Gergő: Erdélyi magyarok és románok a politikai térben. Cluj Napoca, Institutul Pentru Studierea Problemelor Minoritatilor Nationale, 2013.) Ez voltaképpen érthető, hiszen egy rendkívüli képlékeny, homályos és sokrétü fogalomról van szó, az ilyen fogalmak hosszú távú túlélése pedig éppen ezen „sok elágazásnak” köszönheti létét. (vö. Bausinger, ld. 27. lábjegyzet). De Kiss ezt vagy nem tudja, vagy nem akarja tudni, és minduntalan egy kutatói habitustól idegen igazságosztó, szelektív és ezért ideologikusnak is nevezhető szerepben felbukkanva igyekszik kiosztani a perspektívájába került kutatókat, kutatásokat. Távol álljon tőlem a rá jellemző terjengősség (stilisztikai jegyei elemzésétől, indokolatlan minősítéseitől, az erdélyi szakmai nyilvánosságban köztudott Kiss-Veres, nem kifejezetten szakmai jellegü konfliktus hátterének ismertetésétől, „orkozásaitól” ezért most tekintsünk el), de indirekt érintettség okán e vonatkozást ismertetnem kell. Kiss központi „baja” az, hogy a 2007-es Kárpát Panel adatai alapján a válaszadók 65 százaléka azt mondta, az erdélyi magyarok a román nemzetnek is részét képezik. Ezt cáfolandó egy 2012-es felmérésébe ő maga is betette ezeket a kérdéseket, annyival kiegészítve, hogy az alanyokat arra kérte, indokolják meg válaszukat. Kiss adatai alapján a magyarok szintén nagy része (52 százaléka) azt állította, hogy a román nemzetnek is részét képezik, ám a nyitott kérdések csoportosítása alapján, végül Salat egy cikkére hivatkozva úgy értelmezi, a politikai közösségnek létezik egy „mély” és „felszínes” rétege is, a román nemzethez való tartozás pedig ezt a semleges „felszínes” politikai közösségként való létezést sugallja leginkább. (Kiss azonban nem említi, Salat e gondolatmenetet valójában Frasertől veszi át, és mellékesen megjegyzi azt is, hogy mivel a romániai politikai közösség a „nem kész” és „nem teljes” állapottal jellemezheto, itt gyakorlatilag meg kellene haladni ,a felszínes” és „mély” kategóriákat. Sőt, egy román szerzőre hivatkozva, azt is kijelenti, a román politikai közösség „vékony rétege" valójában „üres” kategória. Salat írása részletekben a Korunkban jelent meg, egyben itt is olvasható: Salat Levente: A politikai közösség kérdése a többség-kisebbség viszonyának a nézőpontjából. In: Hatos Pál - Novák Attila (szerk.): Kisebbség és többség között. A magyar és a zsidó/izraeli etnikai és 
mibenlétére vonatkozó klasszifikációs küzdelem egyoldalú tárgyalása: a szerző, miközben a nemzet fogalmát a román nemzet vonatkozásában problematikusnak látja, magyar vonatkozásban ez problémamentesnek állítódik be, mintha eleve adott lenne az, hogy a kisebbségi magyar hasonló módon gondolná azt, hogy a magyar nemzet tagja, mint egy többségi magyar. Ez azt a módszertani hiányosságot is felveti, hogy egyáltalán nem tárgyalja a határon túli magyarok körében létező (negatív) elöítéleteket, sztereotípiákat, amelyek, mint tudjuk, nem csak a többségi nemzet irányába fogalmazódnak meg, hanem a magyar nemzet Magyarországon élö tagjaival (állampolgáraival) szemben is. A későbbiekben látni fogjuk, véleményünk szerint az állampolgárság (és az ehhez kapcsolódó identitások) megértése szempontjából kulcsfontosságú lesz ezen létező elóítélet-rendszerek szerepe.

Egy másik elemzés Kasznár Veronikáé, ${ }^{21}$ aki a 2004. decemberi 5-i népszavazás körüli publicisztikai vitákat elemzi, és

kulturális tapasztalatok az elmúlt századokban. Budapest, L’Harmattan, 2013. 213-258.) Kérdezhetnénk, hol van itt a két kutatás közötti ellentmondás? Kiss behozott egy-két új kérdést, és azok interpretálásakor egy - általa amúgy leegyszerüsített - más kontextusban, más célból kialakított sémát használ fel (és ezúttal tekintsünk el attól is, hogy a segítségül hívott modell a politikai közösség és nem a nemzet értelmezésére jött létre). A központi „baját” azonban minden erőfeszítése ellenére nem tudta orvosolni, sőt, gyakorlatilag az általa kritizált Kárpát Panel adatait erősítette meg, amikor azt írta, hogy 2012-ben azért tünik plauzibilisnek az, hogy „csak” 52 százalék állította azt, hogy a román nemzetnek is részét képezik az erdélyi magyarok, mert időközben intézményesült a kettős állampolgárság. Kiss szerint a Kárpát Panelt vezető kutatókat alaposan „megcsalták a szavak”, mivel talán mást értettek az alanyok a nemzet fogalmán, mint mi. Lehet Kissnek meglepő, de az érvényesség kritériumának a kutatók teljesen tudatában voltak, hiszen nem véletlen, hogy 2009-ben fókuszcsoportos beszélgetéseket is szerveztünk a kérdőívben is érintett témákról, az ez alapján történt elemzéseket (amelyeket éppen saját munkahelye által müködtetett kiadó adott ki, elolvashatta volna Kiss is, ld. Veres Valér - Papp Z. Attila (szerk.): Szociológiai mintázatok. Erdélyi magyarok a Kárpát Panel vizsgálatai alapján. Kolozsvár, Nemzeti Kisebbségkutató Intézet - Max Weber Társadalomkutatásért Alapítvány, 2012.) pedig éppen azért tartottuk fontosnak közölni, hogy ismertessük az alanyok elmesélései alapján is az etnikai kategorizációs küzdelmet, a kisebbségi etnocentrizmus szerkezetét. De mint jeleztük, Kiss szelektál, csak azt veszi észre, ami prekoncepcióját megerősíti.

21 Kasznár Veronika Katalin: Versengő nemzetfogalmak a kettős állampolgárságról szóló 2004-2005-ös publicisztikai vitákban. In: Feischmidt 
kijelenti, hogy e vita tétje valójában nem is a kettős állampolgárság volt, hanem a magyar nemzet definiálása. Akkor ugyanis mintha még képlékeny, formálható lett volna a nemzet fogalma, de ez szerinte a 2010-es állampolgársági törvénnyel lezárult. Véleményem szerint talán e vitát végérvényesen sosem lehet lezárni (vö. Bausinger), esetleg kodifikálni vagy részben zárójelben lehet ugyan tenni, de vélhetően újabb és újabb értelmezések a későbbiekben is felbukkannak. Tény, hogy 2010-ben nem volt már nyilvános vita arról, hogy a kettős állampolgárság milyen kérdésekre adott válasz. Azonban Kasznár írása elemzésünk szempontjából másképpen fontos: azt állítja ugyanis, hogy a vitának volt egy metaszintje, ahol a veszélydiskurzus megjelent. Ez a diskurzus (amely egyébként már a kilencvenes években kötött alapszerződések során is érezhető volt) ellenségképeket kreál, és ami érdekes, hogy a nemzeti és antinacionalista beszédmódban egyaránt megtalálható.

Elemzésünk szempontjából ez azért fontos, mert mi a fókuszcsoportos beszélgetések által az állampolgárságról alkotott koncepciókat a mindennapiságban, a használata és funkcionalitása által, illetve az ezekről alkotott diskurzusok szintjén akarjuk megragadni. Alapfelvetésünk az volt, hogy az állampolgárság intézménye vélhetően kihat azokra az inter- és intraetnikus viszonyokra, amelyben az új törvény adta lehetőség „célcsoportja” él. Ebben a miliőben, a kisebbségi létként aposztrofált helyzetben a veszélyérzettel kapcsolatos narratíva óhatatlanul is jelen van: vagy igenlő (elismerő) módon, vagy - ami itt ugyanaz - tagadás formájában is.

Összegezve e két kiemelt írást, valamint az előző részekben említett Salat gondolatmenetét, azt mondhatjuk, hogy a magyar állampolgárság kérdése a brubakeri koncepcióban tételeződve a kisebbségi társadalom kommunitárius koncepcionalizálását, illetve jövőbeni létét feszegeti. Ad absurdum e véleményekben éppen a korábbi viták elemzése során nyilvánvalóvá vált veszélydiskurzus köszön vissza, amely által éppen az objektívnak láttatott szakértői szerep kérdőjeleződik meg.

Módszertan

Margit és tsai: Nemzet a mindennapokban. Az újnacionalizmus populáris kultúrája. Budapest, MTA TK - L’Harmattan, 2014, 209-248. 
Kvalitatív kutatásunkkal az állampolgárság mindennapi használatát és megítélését igyekeztünk feltárni. Alanyaink zöme nemrégiben lett magyar állampolgár, ezért óhatatlanul a magyar állampolgárság megszerzése körüli történetek is nagy intenzitással merültek fel. Mivel a klasszikus állampolgárság-fogalom a területiségre, a nemzetre is utal, a beszélgetések során az identitás, kisebbségi identitás tágabban értelmezett dimenzióin belül akartuk beazonosítani az állampolgárság „,helyét”.

Megközelítésünket sok szempontból is indokoltnak tartjuk. Elöször is, mint láttuk, a kettős állampolgárság témáját vizsgáló írások elvétve épülnek empirikus anyagokra. Amely pedig valóban empirikus adatokra is épül, ${ }^{22}$ meglehetösen eltávolodik az egyéni motivációk belső megértésétől, és az elemzés átcsúszik politológiai spekulációba, amelynek horizontján egy kommunitárius megközelítés húzódik, azaz azt feszegetik, mi lesz a határon túliakkal mint közösséggel. Ez azért is érdekes, mert a szerző ugyanakkor a csoport nélküli etnicitás brubakeri tézisével is operál, amely éppen azt hangsúlyozza ki, óvakodjunk a csoportként való tételezéstől, hiszen az etnicitás valójában nem dolgok (értsd: csoportok, közösségek) a világban, hanem a dolgok (a világ, társadalom) látásmódja, sajátos percepciója és értelmezése. ${ }^{23}$

Másodsorban azt is tudnunk kell, hogy a nyugat-európai kettős állampolgársággal kapcsolatos vitákat rendszerint egyfajta negatív tónus hatotta át: az értelmezések az állam szemszögéből történtek, és nem egyéni szempontból. ${ }^{24}$ Pedig az egyéni szempontok, ahogy azt például a svédországi vitákat elemző szerző is kihangsúlyozza, gyakran fontosabbak a jogi, politikai szempontoknál. ${ }^{25}$ Ugyanez érvényes a határon túli közegben is,

\footnotetext{
${ }^{22}$ Kiss Tamás: Nemzetdiskurzusok hálójában. Az állampolgárságpolitika, mint a magyar nemzetre vonatkozó klasszifikációs küzdelem epizódja és eszköze. In: Magyar Kisebbség. 2013, 3-4. 7-95.

${ }^{23}$ Ld. Brubaker, Rogers: Csoportok nélküli etnicitás. In: Kántor Zoltán (szerk.): Szöveggyüjtemény a nemzeti kisebbségekröl. Budapest, Rejtjel. 2005. 120.

${ }^{24}$ Hammar, Tomas: State, nation, and dual citizenship. In: Brubaker, Robert (szerk.): Immigration and the Politics of Citizenship in Europe and North America. Lanham. MD, University Press of America, 1989.

${ }^{25}$ Gustafson, Per: Globalisation..., 2002, i.m.
} 
amikor a kettős állampolgárság hatásai a magyar állam vagy a „közösség” jövője szempontjából nyilvánul meg. Ezért azt gondoljuk, hogy a fókuszcsoport félig formális, félig informális beszélgetései alkalmasak arra, hogy megragadjuk az egyéni szintet, és feltárjuk az új állampolgársággal kapcsolatos motivációk narratíváit. Az individuális szinthez kapcsolódó narratívák elemzése tehát azért fontos, mert a korábbi elemzésekből, reflexiókból ez kimaradt, másrészt pedig azért, mert az állampolgárság nem csak jogi kapcsolatot, hanem individualizációt és újfajta identitások kialakulását is jelenti.

Kutatásunk során kilenc fókuszcsoportos beszélgetést végeztünk négy környező országban: kettőt-kettőt Szlovákiában, Kárpátalján, Vajdaságban, és hármat Erdélyben (kettőt Székelyföldön, egyet Kolozsváron). A beszélgetésekbe egyaránt igyekeztünk állampolgárságot már igényelt, illetve nem, vagy még nem igényelt személyeket is bevonni. Arra is törekedtünk, hogy az egyes beszélgetéseken fiatalabbak és idősebbek is jelen legyenek. A beszélgetések vezérfonala kialakítása során az egyéni kötődések feltérképezése után a szülőföld, haza, nemzet tagság kérdéseit céloztuk meg, majd pedig az állampolgárságról általában, illetve speciálisan a „régi”, illetve az új magyar állampolgárságról kérdeztük alanyainkat. Kíváncsiak voltunk arra is, hogy e felvetések előhozzák-e az alanyokból a 2004. december 5-i népszavazás témakörét, és ha esetleg ez spontánul nem jött volna elö, a moderátor a vélemények előcsalogatása céljából szembesítette az alanyokat azzal, hogy a kettős magyar állampolgárságnak nemrégiben volt egy ilyen „fogadtatása”.

A gazdag kvalitatív anyag összes szegmensére ${ }^{26}$ jelen elemzés keretében ezúttal nem térünk ki, hanem csak központi kérdésünket, az elöítélet-világ, a kisebbségi élethelyzet önértelmezése és az állampolgársághoz tapadó identitások találkozását fogjuk tárgyalni. Módszertanilag azt is le kell szögeznünk, hogy messzemenően egyetértünk azzal, amit Bausinger állít a haza kapcsán: a fogalom pont azért élte/éli túl az évszázadokat, mert nincs egyértelmü

\footnotetext{
${ }^{26}$ Az elhangzott beszélgetések szó szerint átirata után az interjúkat az Atlas.ti programban kódoltuk.
} 
definíciója. ${ }^{27}$ Minden definíció kizár, lezár, és így a fogalom túlélésének ad kisebb esélyt. Ha elismerjük a fogalmak képlékenységét, akkor beláthatjuk azt is, hogy éppen számtalan leágazása, a sok homály által élhet folyamatosan tovább, és ami még izgalmasabb, újabb és újabb jelentéseket kreálhat vagy szippanthat be. Ez igaz az olyan - kutatásunk által is érintett - fogalmakra is, mint a nemzet, a szülöföld vagy akár az állampolgárság is. Éppen ezért a célunk mindössze annyi, hogy az elhangzott beszélgetések alapján felfejtsük alanyaink állampolgárság-konstrukcióit, narratíváit, amelyeket majd - kívülálló kutatóként - rendszerezni fogunk. Mivel e fogalmak képlékenyek, „mozognak”, azt is állítjuk, hogy a leírt narratívák egy adott tér-idő komplexumban nyernek értelmet. Röviden, nem szeretnénk abba a tévhitbe esni, hogy ezeknek a fogalmaknak van egyértelmü, lezárt definíciója. ${ }^{28} \mathrm{Ez}$ ugyanakkor érvényes úgymond horizontálisan is: a kisebbségi lét és állampolgárság társadalmi konstrukcióit ugyan egységes keretben tálaljuk, de tudatában vagyunk, hogy a kisebbségi életformák megélése, interpretációja másfajta alakzatokat ölt az egyes régiókon belül. ${ }^{29}$ Célunk azonban az, hogy tértől függetlenül, a lehetséges közös jegyeket, jellemzőket diszkurzíve a felszínre hozzuk.

\section{Kisebbségi identitások: kötödések szintjei és a viszonyulások}

Nem egyszerü a kisebbségi identitásról bármit is mondani, hiszen ez azt feltételezi, hogy ez egy eleve adott entitást jelöl. Megközelítésünkben viszont elismerjük azt, hogy az etnicitáshoz kapcsolódó identitás is csak egy konstrukció, amely bizonyos kategóriák gyakorlati alkalmazásán keresztül lesz érthető. Akárcsak az etnicitás, az identitás „nem van”, hanem aktualizálódik bizonyos konkrét helyzetekben, a világ dolgainak látásmódja, illetve az

\footnotetext{
${ }^{27}$ Bausinger, Hermann: A haza fogalma egy nyitott társadalomban. In: Regio. 1991, 4. 3-14.

${ }^{28}$ Mondhatnánk azt is, csak konstrukciók léteznek, amelyeket kutatók kreálnak, ki ideologikusabban (mint például Kiss megidézett cikke), ki kevésbé - de ennek megítélése is nehéz.

${ }^{29}$ Ennek érzékeltetése szempontjából a felhasznált idézeteknél jelezzük, hogy melyik régióban hangzottak el.
} 
önreprezentáció eszköze. ${ }^{30}$ A fókuszcsoportos beszélgetések ugyan mesterséges beszédhelyzetek, de az itt létrejövő diskurzusok vélhetően olyan társadalmi praxisokra utalnak, amelyek jelentőséggel bírnak az alanyok számára.

E bizonytalanságok belátása mellett a kisebbségi identitás szerkezetének vizsgálatakor mi is a brubakeri analitikus felosztásból indultunk $\mathrm{ki}^{31}$ mert azt feltételeztük, hogy az „új” magyar állampolgárság által beindított identitások következtében az egyének valamilyen módon viszonyulnak a saját államhoz/többséghez, Magyarországhoz és tételezett saját kisebbségi közösségükhöz is. Mindez azért „,vállalható” az állampolgársághoz kapcsolódó identitás megértése szintjén, mert egy kettős állampolgárnak hivatalosan és/vagy informálisan is viszonyulnia kell a kétfajta állampolgárságához (vagy annak lehetőségéhez). Az ezekhez kapcsolódó identitáslehetőségeket ugyanakkor ötvöznie kell saját szükebb világán belül, illetve önértékelése során is. Ez a belső ötvözés történhet egyértelmủen esszencialista vagy kultúrnemzeti módon, amikor az alany a magyar mivolta megvallása által, érzelmi alapon egyenes vonalú fejleményként értelmezi a magyar állampolgárság megszerzését. Sőt, kifejezetten hálás azért, hogy Magyarország megszólította e magasztos dologgal:

„Én fóként érzelmi okokból csináltattam a magyar állampolgárságot. Hát, az elsők között, vagy legalábbis a legelején, amikor megnyilt ez a lehetöség, mi beadtuk. Nekem fontos volt az, hogy nem tudom, az odatartozásomat egy kicsit ez erösítette." (5. sz. interjú, Kárpátalja)

${ }^{30}$ Az identitásfogalmak inflálódásáról ld. Stachel, Peter: Identitás. A kortárs társadalom- és kultúratudományok egy központi fogalmának genezise, inflálódása és problémái. In: Regio. 2007, 4. 3-33. Az etnicitás kategóriákban és kategóriákon keresztül való müködését kisebbségi és többségi aszimmetrikus (magyar, román) világokban, Kolozsvár példáján keresztül ld. Brubaker, Roger Feischmidt Margit - Fox, J. - Grancea, Liana: Nacionalista politika és hétköznapi etnicitás egy erdélyi városban. Budapest, L’Harmattan, 2011. 219252.

31 Brubaker, Rogers: Nationalism Reframed: Nationhood and the National Question in the New Europe. Cambridge University Press, 1996. 
„Eddig a nép érezte az országot magáénak, és most az ország kezdi a népét magáénak érezni, és ennek ez a kifejezésmódja, hogy meghívja öket, megadja a lehetöséget, hogy váljanak papíron is [magyar állampolgárokká].” (5. sz. interjú, Kárpátalja)

De ugyanakkor számolnunk kell azzal is, hogy a kétféle kötődés egy sajátos vagy kevert identitás vállalását is jelenti, de ezáltal az egyén nem érzi magát „kognitív disszonanciában”, hiszen éppen vállalt hibriditása teremti meg a mindennapisághoz szükséges belső egyensúlyt. A kétféle kötődés ebben az esetben pozitív kicsengésü, ám találkozhatunk olyan esettel is, amikor diszkurzív szinten az egyensúly éppen a kölcsönös taszítások vagy határtermelés által valósul meg.

„Mert itt a szlovákoknak hülye magyarok vagyunk - már bocsánat -, a magyaroknak meg, már sok helyen hallottam, hogy buta tótok. Ezért egyikkel sem tudok így igazán azonosulni ... De alapvetöen magyarnak gondolom magam." (1. sz. interjú, Szlovákia)

„....hát nekünk itt, szerintem... hát ha nem is dupla identitással, de mégis olyannal kell élni, mert meg kell öriznünk, normális esetben megórizzük a magyarságunkat, úgy kell csinálnunk, hogy magyarok maradjunk itt. De valamilyen szinten furán hangzik így kimondva, de valamilyen szinten ukránok kell legyünk, ukrán félék kell legyünk, csak a mindennapi élethez." (6. sz. interjú, Kárpátalja)

Ez az utóbbi idézet azt is igazolja, amit a korábbiakban már az állampolgárságok hierarchiájáról jeleztünk Spiro nyomán. Itt ugyan identitásról van szó, de jelzi azt, amit az állampolgárság kapcsán is állít: az egyik állampolgárság (és az ehhez kapcsolódó identitás) érzelmi szempontból, a tételezett etnikai közösség fennmaradása szempontjából fontos, a másik pedig a mindennapi életvitelhez szükséges. Igen ám, de éppen az domborodott ki a beszélgetésekből, hogy már a saját világ is nagyon heterogén, referenciális és gyakran polarizált. Ugyan kívülröl hajlamosak vagyunk egységesnek gondolni a kisebbségi közösséget, valójában 
belül nagyon differenciált. Ez egyértelmüen megmutatkozik az egyének közösségi hovatartozását firtató kérdésre adott válaszok alapján is, hiszen a legtöbb esetben lokális, regionális kötődéseket említettek, a tágabb „magyar” kategória csak ezután következett. A regionális kötődéseken belül azonban identitáspolitikai perspektívájú értelmezések jöttek elő: Szlovákiában éles különbséget tesznek a felvidéki és szlovákiai magyar között, Erdélyben az „erdélyi magyar” és „székely” között, Vajdaságban a „vajdasági” és „délvidéki” között, Kárpátalján pedig a „kárpátaljai magyar” kifejezés relativizálódott. Az identitáspolitikai perspektíva mondhatni oda-vissza hat, hiszen egyaránt egy sajátos történelmi helyzet felfogására, illetve egy jövőbe mutató integrációs lehetőségre is kihat. A „felvidéki” kategória vagy a „délvidéki” identifikáció például nem csak történeti szemléletről, hanem a magyar állampolgársághoz vagy nemzethez való viszonyra is kihat.

„Z.: Én a magam részéről szívesebben használom a szlovákiai magyar kifejezést, de egyébként szimpla magyar vagyok, úgyhogy énnekem... én bevallom öszintén, hogy önmagában azt a kifejezést nem szívesen használom, hogy felvidéki. (...) Úgy tartom, ez most divatba jött. Felvidék, mint olyan, 1938-tól 45-ig létezett, illetve elötte... 45 óta tulajdonképpen ... az már, az, hogy felvidéki vagyok... az már olyan... én a magam részéröl cikisnek tartom. Énszerintem itt most nincs Felvidék. Ez az én privát véleményem. Itt most Szlovákia van és én szlovákiai magyar vagyok, de szimpla magyar és magyar, attól függetlenül, hogy nem felvidéki.

L.: Történelem tanár voltam, meg vagyok.. Mindig azt mondtam, egyetlen magyar nemzet létezik, elöször is. Mindegy, hogy Amerikában vagy bárhol élünk, egy magyar nemzet létezik. Ennek bizonyosképpen tehát aztán tagja lehet a felvidéki magyar is - ezzel semmi gond nincs, hogy felvidéki magyar -, meg az erdélyi magyar és a többi. Ebböl következik, hogy egy magyar nemzet létezik. Ez a megkülönböztetés egyrészt földrajzi dolgokból adódott, másrészt pedig abból adódott, ami Trianon következménye, hogy tagadjuk, hogy egy magyar nemzet van." (Szlovákia, 1. sz. interjú) 
„,...attól függ, hogy az ember melyiket használja, hogy mi a célja vele, a vajdasági az a szerb államhoz kötödik, a szerbséghez, az egész kifejezés a 48 utáni szerb Vajdasághoz kötödik, meg egyáltalán az Szerbián belül egy politikai közösség. A Délvidék meg egy magyar történelmi régió lenne, ez a logikája, de szerintem ez nem ilyen tudatos." (4. sz. interjú, Vajdaság)

$\mathrm{Az}$ egyik kárpátaljai beszélgetésben többen is amellett érveltek, hogy a kárpátaljai magyar kategória értelmiségi konstrukció, miközben a mindennapiságban a magyarországiaktól való elkülönülésben az „ukránok” megnevezést használják magukra, annak ellenére is, hogy a nyelvet nem is ismerik (ez önmagában nem meglepö, hiszen Ukrajna lakosságának jó része szintén nem ismeri/használja az ukrán nyelvet). Magyarországról nézve kárpátaljai magyarokat „láthatunk”, de közelröl megpillantva ukránul nem beszélő magyar anyanyelvü „ukránok”, magyarok és romák is vannak.

„Én nagyon sokkal találkoztam, aki például ukránnak nevezi magát, és csak azért, hogy megküiönböztesse magát például a magyarországiaktól, szerintem. De egy szót se tud ukránul, de magát ukránnak... (...)

Szerintem, aki így nevezi magát, hogy kárpátaljai magyar, az a többi határon túli magyartól akarja kicsit magát, nem rossz értelemben, vagy pejoratív értelemben megkülönböztetni magát, és ez azért fordul elö szerintem inkább az értelmiségi körökben, mert a legtöbben nem mennek el külföldre, vagy akár Magyarországon is, ugye, ott általában ukránnak nevezik őket, de nem feltétlenül találkozik másik határon túli magyarral." (5. sz. interjú, Kárpátalja)

A saját kötődések viszonylagossága a haza fogalmának szintjén is tetten érhető - szemben a szülőfölddel például, amely körül nagyjából konszenzus volt. ${ }^{32}$ Míg a szülőföld az a lokális hely,

\footnotetext{
32 A haza, otthon fogalmának különféle értelmezéseinek áttekintését ld. még: Bárdi Nándor: Otthon és haza. Tanulmányok a romániai magyar kisebbségek történetéröl. Csíkszereda, Pro Print, 2013. 9-18.
} 
ahol születtek és (gyerekként) éltek vagy élnek, addig a haza már relativizálódik és szintén identitás-perspektívában értelmeződik. A haza lehet ugyan az otthonosságot nyújtó szülőföld is, de lehet térhez kötött, spirituális entitás is. A haza alatt (Nagy-)Magyarországot vagy Kárpát-medencét értők számára a magyar állampolgárság kvázi természetes jogként csapódik le ${ }^{33}$ míg a haza alatt inkább a saját országot, térséget értők számára az állampolgárság jobbára kiegészítő jellegü, a magyar nemzet, de egy másik ország „adománya”, amely egyénileg (pragmatikus vagy érzelmi okokból) választható is, meg nem is. A Kárpát-medencei hazában élők valójában nem „választhatnak”, míg a szükebb területtel beazonosítható „ország-hazában” élők élvezhetik a választás (nemzeti) szabadságát. A hazáról szóló mindkét beszédmód azonban nagyon gyakran a hazátlanság témakörét hozta be, és e perspektívából az állampolgárság óhatatlanul is a bizonytalanság feloldására szolgáló, a biztonságot nyújtó nemzeti keretként jelenik meg. Ez viszont nem jelenti azt, hogy a haza és az állampolgárság nem teljes kongruenciájából fakadó feszültség feloldódna:

„Én vajdasági vagyok, én itt születtem, nekem ez a szülöföldem, a Vajdaság a hazám. De megerösitést kapok, és biztonságérzetet kezdek most érezni." (4. sz. interjú, Vajdaság)

„Itt magyarok vagyunk, Magyarországon meg ukránok, és én pont azt mondanám, hogy hontalanok lehetünk. Én azt érzem, hogy kicsit olyan hontalan vagyok. Szülöföldem van, de kimondottan hazám pont azért nincs, mert itt így néznek rám, ott meg úgy.” (6. sz. interjú, Kárpátalja)

„Én szerintem a legtöbb határon túli magyarban van egy ilyen kettös érzés, hogyha azt mondjuk, hogy haza, mert van egy magyar haza, és van Ukrajna, amit nem tudunk megtagadni, mert ugye, hogy mi itt születtünk, és ez is nekünk a hazánk, és szeretnénk, hogy itt is jó legyen. (...) Van egy itteni kötödésünk, és ezért bármiképpen próbáljuk ezt tagadni, azért van egy ilyen

\footnotetext{
${ }^{33}$ Vö. az arendti gondolattal, miszerint az állampolgárság ,,jog a joghoz”. Arendt, Hannah: The Origins of Totalitarianism. Cleveland-New York, The World Publishing Company, Meridian Books, 1951. 294.
} 
kettös érzésünk, hogy igen, van a Magyarország, a NagyMagyarország, és akkor mi magyarok vagyunk, ahhoz tartozunk, de van egyfajta kötödésünk, mert hogy itt születtünk, és ezt nem tudjuk felülírni." (5. sz. interjú, Kárpátalja)

Interjúalanyaink önmagukat magyarnak valló személyek voltak, a beszélgetések is magyar nyelven zajlottak, így abban semmilyen különleges nincs, hogy a (kisebbségi) magyarsághoz való tartozás kritériumaként a magyar nyelv és kultúra ismerete dominált. E kultúrnemzeti koncepció domináns jellege mellett azonban éppen a határesetek, a magyarság definícióinak „liminalitása” ${ }^{34}$ kapcsán elöjövő narratívák tanulságosak. Alanyainknak felvetettük, hogy például a nyugati diaszpórában lehetséges az is, hogy valaki ugyan nem beszéli a magyar nyelvet, de magyarnak érzi magát. ${ }^{35}$ Kultúrnemzeti pozícióból ezt természetesen ellenezték, de ugyanakkor felbukkant az állampolgárság megszerzésével összefüggő narratíva is. Diszkurzív szinten elismerték ugyanis, hogy vannak olyanok, akik úgy szereztek magyar állampolgárságot, hogy nem bírják a magyar nyelvet, ez pedig természetesen ellentmond az etnokulturális közösségként értelmezett állampolgári fogalomnak, az ethnizenshipnek. Ezt egyik narratívában a könnyített honosítással kapcsolatos visszaélésekkel magyarázták, és ilyen szempontból negatív keretben mutatták be, sőt egészen addig elmenve, hogy ilyen módon a szolidaritás is megkérdőjeleződik: egyik alanyunk azt is közölte, hogy éppen azért nem akar magyar állampolgárságot igényelni, mert nem akar közösséget vállalni az ilyen (,liminoid”) személyekkel. Egy másik narratívában azonban már pozitív értelmet is nyert e definíciós bizonytalanság, és a magyar állampolgárság „liminoid” igénybevétele a nemzet határainak meghosszabbításaként került értelmezésre - és mint ilyen nem csak elfogadható, hanem éppen a kisebbségi helyzethez tapadt bizonytalanságérzet felszámolásának eszköze is.

\footnotetext{
34 A liminalitás újabb értelmezéseit lásd: Thomassen, Bjorn: The uses and meaning of liminality. In: International Political Anthropology. 2009, 2. 5-27. ${ }^{35}$ Ld. erről részletesebben: Papp Z. Attila: Beszédből világ. Elemzések, adatok amerikai magyarokról. Budapest, Magyar Külügyi Intézet, 2008.
} 
„Különben én ezt (...), borzasztóan pozitívnak élem meg. Énnekem rengeteg barátom most már, akik szerbek, sziát köszönnek, szegény próbál ökögni, makogni, mondja nekem, én röhögök... persze ez pozitív értelemben. Mondja, hogy segíts, akkor én segítek. Aki megkapja a magyar állampolgárságot, én szerintem többet énvelem gondja nem lesz... Tehát hogy mondjam... Én ezt a magyar kormány részéröl én ezt olyan pozitívnak, egy ilyen biztonságérzetnek fogom föl, hogy hát aki megkapja a magyar állampolgárságot, az többet énrám nem fog mutogatni, mert, mert hát ő is magyar... tehát, hogy mondjam, hogy... öneki most van érdeke, hogy magyar legyen, én meg akkor örülök neki, hogy had legyen, ha ö az akar lenni, énnekem totál nem." (4. sz. interjú, Vajdaság)

Egy korábbi (a kettős állampolgárság 2010-es intézményesülése elötti) kutatásunkban is tetten értük már erdélyi vonatkozásban azt a kisebbségi etnocentrizmust, amely valójában a magyarországi magyarokat is ,idegenként”, azaz - a különbségeket negatívan kihangsúlyozó - etnicizált látószögben jeleníti meg. ${ }^{36} \mathrm{~A}$ jelen kutatásban is rákérdeztünk arra, hogy milyennek tekintik a magyarországi magyarokat? Ez a kettős állampolgárság keretében azért érdekes kérdés, mert ha azt feltételezzük, hogy a magyar állampolgárság kulturális megalapozottságú nemzeti alapú szolidaritást is jelent, akkor a nemzet tagjai közötti is valahogy érvényesülnie kell e szolidaritásnak. Csakhogy az elöítéletek rendszerében úgy tủnik, nem történt változás: ugyan elhangzottak pozitív vélemények is a magyarországi magyarokról (,udvariasak”, „van, amit tőlük is tanulni” stb.), avagy magyarországi intézményekről, a leggyakrabban mégis a lényeges eltérések tematizálódtak: a magyar-magyar határtermelés folyamatosnak mondható, és különösen éles akkor, ha a nemzethez vagy magyarsághoz való viszonyról, esetleg szimbólumok használatáról van szó. Úgy is fogalmazhatunk, hogy van egy áthidalhatatlan strukturális különbség, egy láthatatlan korlát: ${ }^{37}$ a nemzethez tartozás

\footnotetext{
${ }^{36}$ Veres Valér - Papp Z. Attila (szerk.): Szociológiai mintázatok... 2012, i.m.

${ }^{37}$ Vö. Bausinger leírásával miszerint ,társadalmunkban a 'láthatatlan korlátok' és a 'finom megkülönböztetések' a kulturális habitus jellemzői”. Bausinger, Hermann: Népi kultúra a technika korszakában. Budapest, Osiris, 1995, 9.
} 
a magyarországi magyaroknak természetes, ezért ez semmilyen kihívást nem jelent számukra, a határon túli világokban viszont ez egy emocionálisan is determinált sorskérdés. Ez a strukturális adottság visszahull a határon túli magyarok körében élö előítéletekre: mint jeleztük, elismerjük, hogy nem tényleges etnikai csoportokról van szó, az etnicitás mint sajátos különbségteremtő látásmód azonban éppen e magyar-magyar viszonyban mutatkozik meg a legmarkánsabban.

„A budapesti magyarokról nem vagyok olyan túl jó véleménnyel, úgy gondolom, hogy nagyon távolságtartóak. Azért 7 év alatt egy kezemen meg tudom számolni, hogy hány budapesti barátom lett, és hogy hányhoz mentem például haza. És úgy érzem, hogy nem nulláról kezdi az ember - legalább nulláról -, amikor valakivel megismerkedik, hanem valahonnan a mínuszból, tehát ez az a távolságtartás, amit éreztem folyamatosan, illetve az a bizalmatlanság. Míg itthon valahogy nem tudom, melegebbek az emberek." (3. sz. interjú, Vajdaság)

„Abban nem vagyok biztos - és nem szeretnék általánosítani -, hogy miután az egyszerüsitett honositási eljárással majd felvesszük a magyar állampolgárságot, attól majd a magyarországi magyarok elkezdenek máshogy nézni ránk. Tehát ugyanúgy vajdasági magyar leszek az ö szemében, nem fog másként nézni rám. Ez tényleg nekünk jelent valamit, nekik ez ugyanúgy egy ilyen külön kaszt vagy külön csoport lesz mint azelött, egy külön csoport, tehát ebböl a szempontból ez nem fog változni." (4. sz. interjú, Vajdaság)

„XY bácsi már meghalt, ö össze-vissza csókolta a magyarigazolványt, amikor átvette... egyszerüen ... ö magyar állampolgár [volt valamikor], '12-ben vagy mikor született az öreg, és neki ez lelkileg... (...) Kirakta az összes II. világháborús kitüntetését, és sírt az öreg, amikor ezt megkapta. Szóval a jelképeket ti ott nem fogjátok fel, itt mi jobban [értékeljük]" (2. sz. interjú, Szlovákia)

A kisebbségi etnocentrizmus jelenségének van egy elméleti és egy gyakorlati vonatkozása is. Elméleti szinten felhívja a figyelmet 
arra, hogy az eddigi, állampolgárságról szóló fejtegetésekben (lásd például Salat és Kiss már idézett írásait) szinte egyáltalán nem jelent meg ezen viszonyulások szerepe. Pedig a nemzet, akár a magyar nemzeti tagság fogalmát szintén nem lehet egységesnek, homogénnek elgondolni, hiszen ez a „csoportizmus”38 csapdáját rejtegeti. A nemzet határait, belső tagoltságát szükséges újraértelmezni, hiszen a nemzet is egy konstrukció, nem öröktől fogva adott entitás, hanem folyamatában érhető tetten. Relatív újkeletủ szakirodalmi irányzat szerint szuperdiverzitásnak hívják azt az irányzatot, amely a statikus etnicitásfogalmat meghaladva azt állítja, hogy „új változók” mentén lehet úgy árnyalni a csoporthovatartozást, hogy az visszaadja az etnicitás dinamikáját. A csak etnicitásra koncentráló megközelítés által nem érthetjük meg az egyéni döntéseket, a kizáró és befogadó praxisokat. ${ }^{39}$ Ez a megközelítés, amely egyébként sok ponton találkozik Brubaker etnicitást meghaladó elképzeléseivel is, azt is jelenti, hogy az intraetnikus ellentétek sokkal lényegesebbek az interetnikus kapcsolatok esetleges konfliktusos mivoltánál.

Számunkra ebböl az is következik, hogy a magyar kettős állampolgárság esetleges kihatásait nem érthetjük meg a magyarmagyar tagoltság figyelmen kívül hagyásával. Innen levezethetjük a kisebbségi etnocentrizmus azon gyakorlati hasznát is, miszerint talán éppen e jelenség tudja majd megakadályozni a határon túli magyarok diaszporizálódását, illetve Magyarországhoz való intenzív kapcsolódását: a határon túli magyarokat - túl a tényleges, jogi szempontból is megragadható másodlagos állampolgári mivoltukon - a mindennapokban továbbra is láthatatlan korlátok fogják elválasztani a „magyarországiaktól”. E kulturális habitusok, elöítéletek újtratermelődése pedig éppen a „kisebbségi lét” meghosszabbítását okozzák.

\section{Állampolgárság igénylésének motivációi}

\footnotetext{
${ }^{38}$ Ld. Brubaker, Rogers: Csoportok nélküli etnicitás... 2005, i.m.

${ }^{39}$ Vertovec, Steven.: Super-diversity and its implications. In: Ethnic and Racial Studies. 2007. 29 (6). 1024-54.
} 
A fókuszcsoportok szintjén természetesen kitértünk az állampolgárság igénylésének motivációira is. Az egyik jellegzetes válasz az érzelmi, családi kötelékekre, ,gyökerekre” való hivatkozás. E kontextusban a magyar állampolgárság igénylése egyfajta elégtétel, illetve kötelesség az egykoron szintén magyar állampolgársággal rendelkező felmenőkkel szemben. Ennek elmulasztása családi szinten is negatív erkölcsi megítélés alá esne, hiszen ez egy olyan lehetőség, amely a családi vagy akár a helyi közösségben normatív erővel bír.

„Érzelmi, tehát nemzeti hovatartozás miatt kértem az állampolgárságot, és ugye eztán kötelesség, tehát nem egy olyan dolog, amit most nekem választani lehet, hanem hogyha nagyapám látná azt, hogy én nem kérem, akkor akkora taslit kapnék egyet, hogy csak na... Szóval ez kötelességünk nekünk kérni, ha lehetséges, tartsák ott számon a mi neveinket is. Ne csak Bukarestben tartsák számon, Budapesten is [tartsák számon] a mi nevünket, mert jobb helyen van ott, mint Bukarestbe." (7. sz. interjú, Kolozsvár)

A fenti részletben az is megmutatkozik, hogy „tiszta okok” valójában nincsenek, a különféle jellegü motivációk egymásba mosódnak. A családi, érzelmi, erkölcsi és „nemzeti” okok mellett ugyanakkor megtörténik az anyaország szerepére, felelősségére való hivatkozás is. Fontos rögzítenünk továbbá, hogy az állampolgárság igénylése egyénileg, esetleg családi szinten történik, ezért e mozzanatban egyfajta individualizáció, illetve - ha családi jellegü igénylés történt - kisközösség jellegü szolidaritás érvényesül. A kettős állampolgárság határon túli magyar kontextusban az anyaország általi megszólításra, elismerésre adott egyéni döntés eredménye, és ez egyéni felelösséggel is jár, ha másért nem, azért bizonyára igen, hogy ezt (több nemzetiségü környezetben különösen) vállalni kell. A könnyített honosítás folyamatában tehát egyaránt benne van az individuális mozzanat, de ez az egyéni döntés végül egy tágabb perspektívájú azonosulást is feltételez. A beszélgetésekben nagyon szépen körvonalazódott, hogy akár a kezdeti ellenállás, dac ellenére, az egyéni (néha családi kényszer hatására hozott) döntés után, az ünnepi eskütétel alatt az egyének mintha megszüntek volna létezni, és a magyar nemzet részeként 
élték meg új állapotukat. A nemzetben való ünnepi feloldódás ugyanakkor biztonságot, védelmet nyújt: mint a gyerek anyja mögé, úgy bújhat meg az egyén a nemzet mögé az ellenségesnek tételezett, többségiek által dominált környezetben.

E klasszikus anyaországi védelem mellett, illetve az érzelmicsaládi hagyományokba ágyazott motivációkon kívül pragmatikus (egészségügyi ellátás, munkavállalás Magyarországon vagy más országban, könnyebb határátkelés a kárpátaljaiak és vajdaságiak esetében stb.) célok is gyakran megfogalmazódtak. Ezeket vagy tisztán pragmatikus öncélként azonosíthatjuk be, vagy a diszkurzív stratégia szintjén szublimálva, azaz a családi hagyományba ágyazottan, de akár a többi részvevővel, vagy a beszélgetést lebonyolító „magyarországiakkal” szembeni érzelmi, etnokulturális elvárások alatt jelentek meg.

„Maga az a rész, amikor az esküt tesszük le az egy ilyen jól eső dolog, de én úgy éreztem, hogy bennem semmi különöset nem változtatott meg, tehát én az állampolgárság nélkül is magyarnak éreztem magam. Annyi hogy két nagyon fontos dolog végett kellett, az egyik, hogy ne legyen drága az útlevelem (...). A másik pedig, hogy legyen egy magyar lakcímem, ahová rendelni tudok például az internetröl. Nekem ennyi volt, ettöl nem lettem magyarabb vagy nem magyarabb." (3. sz. interjú, Vajdaság)

„Hát a Gyurcsány elképzelés után - hogy köszönjük, nem kérünk benneteket - úgy voltam vele, hogy hát én sem kérem az állampolgárságot, és akkor egyszer így szólt a faterom, hogy 'ja, gyere, izé, eskütétel, stb.' 'Mi van?' Most már mindegy. Na jó, ott azért egy kicsit megint ez a más érzés. Mindjárt az ember többnek érzi magát, és akkor hát ez így van. Túléltem, nem baj. (...) De nem volt cél se az, hogy papír, se az, hogy utazzak, hát én ilyen helybeli vagyok. De most már úgy kezdem érzékelni, hogy egy-két haver elment oda, London, stb., hogy azért sokszor többszörös fizetésük van, ugyanazzal a tudással, sokkal gyengébb tudással, és akkor így elgondolkodik az ember, hogy lehet, mégsem lesz olyan rossz." (3. sz. interjú, Vajdaság)

„Van a lelki vetülete inkább, hogy az egy megtisztelö érzés, ha papíron is állampolgára vagy a magyar államnak. Én legalábbis 
személy szerint Magyarországot, de nem csak a mostani Magyarországot tekintem, én a régi Magyarországot tekintem egyben lelkiekben. A második, inkább elhanyagolható oka, hogy mint magyar állampolgár, sokkal több lehetöségem van nyugat fele és a világ fele kilépni." (9. sz. interjú, Erdély)

\section{Kisebbségi magyar állampolgárság-konstrukciók}

Tanulmányunkban a kettős magyar állampolgárságot egy új keretben értelmezzük, nevezetesen a kisebbségi identitás perspektívájából, a mindennapi élethelyzetekhez kapcsolódó lehetséges funkciói felöl. E kontextusban az „új” állampolgárság megítélése sok szempont szerint a „régi” kisebbségi élethelyzetekhez kapcsolódó identitásokat árnyalja, a saját helyzet megélésének újfajta lehetőségeit hordozza. Ez annál is inkább így van, mert a „magyar” kategória kisebbségi helyzetben korábbiakban nem hordozta az állampolgári identitást, ${ }^{40}$ sőt magyarnak lenni nem feltételezte a magyar állampolgárság létét.

A kisebbségi identitás és az új kettős állampolgári identitásból levezethető fogalmi ellentétpárok két szempont miatt is indokoltak. Egyrészt ahogy azt a bevezető részben is körüljártuk, az állampolgárság kapcsán az identitás kérdése jelent szociológiai értelemben nagyobb kihívást, hiszen minden állampolgárság identitásokat hoz müködésbe, ${ }^{41}$ a két (kisebbségi és ,új” állampolgári) kötődés mindegyike pedig sajátos identitáslehetőségeket hordoz. Másrészt az ellentétpárok felállítása ugyan sarkítja a kétféle identitástípus különbségét, de mégis Koseleck vagy Weber nyomán - azt állíthatjuk, segíti megérteni e vizsgált tényezők dinamikáját. A mesterségesen szembeállított identitásalakzatok nem arra utalnak, hogy gyökeresen új beállítódások jönnének létre a kettős állampolgárság elérésének lehetősége által, hanem arra, hogy - empririkus anyagunkra

\footnotetext{
${ }^{40}$ Szemben a többségi (román, szerb stb.) kategóriával, amely állampolgárságot és etnikai hovatartozást is jelölt. Ld. Brubaker, Roger és társai: Nacionalista politika.... 2011, i.m., 226.

${ }^{41}$ Spiro, Peter.: Accepting (and Protecting) Dual Citizenhip for Transborder Minorities. In: Bauböck, Rainer (szerk.): Dual Citizenship for Transborder Minorities? How To Respond For The Hunagrian-Slovak Tip-For-Tat? EUI Working Papers, RSCAS, 2010, 75. 7.
} 
támaszkodva - az új jelenség megértése során szembeállítható, egymást kiegészítő habituális lehetőségek vagy egyéni életstratégiák bontakozhatnak ki.

A kisebbségi identitás területiséghez kötött, szervezőelve a ,jus soli”, amely a megszerezhető magyar állampolgárság, az ethnizenship által átalakul ,jus sanguinis" elvvé. A területiséghez kötött „szülőföldön való maradás” paradigmája ugyanakkor könnyen átválthat migrációs potenciálba az új útlevél megszerzése által, sőt, a magyar útlevél érdekes módon még anyagi szempontok alapján is könnyebben elérhető. A kisebbségi (nemzetiségi) identitás valójában nemzeti keretben, elsősorban a többségi nemzetállam létezése által elöhívott lojalitás-rendszerként értelmeződött. A kettős állampolgárság viszont transznacionális keretben gondolható el, és ehhez szorosan kapcsolódik az, hogy föleg a migrációs lehetőségek mellett, a magyar állampolgárság vagy útlevél harmadik országokban is relevanciával bír. Ezért is van nagyobb súlya a magyar útlevélnek, mint a korábban, a státustörvény által megszerezhető Magyar Igazolványnak, amely az esetleges érzelmi igény kielégítésén túl csak az anyaországban bírt gyakorlati relevanciával. A magyar útlevélbe viszont az értelem és érzelem, a pragmatikus és az etnikai-emocionális vonatkozások egyaránt belesürüsödnek, és ugyanakkor megszabadulnak a „régi” állampolgársághoz és útlevélhez tapadt magyarországi és más országokba való utazáskor tapasztalt szégyenérzettől is. ${ }^{42}$

$\begin{aligned} & \text { A kisebbségi és a kettős állampolgárságból eredeztethetö } \\
& \text { identitáselemek }\end{aligned}$
\begin{tabular}{|l|l|}
\hline A kisebbségi identitás elemei & \multicolumn{1}{c|}{ A kettős állampolgárság identitáselemei } \\
\hline "jus soli" & "jus sanguinis" \\
\hline helyben maradás perspektívája & kivándorlás lehetősége \\
\hline nemzeti keretben értelmeződik & $\begin{array}{l}\text { transznacionális - „harmadik” országban is } \\
\text { releváns (ezért több mint a Magyar Igazolvány) }\end{array}$ \\
\hline Magyar Igazolvány & útlevél \\
\hline
\end{tabular}

42 Brubaker és társai fejtik ki a Kolozsvárról szóló könyvükben, hogy az állampolgárság megélése gyakran stigmává vált. Ld. Brubaker, Roger Feischmidt Margit - Fox, Jon - Grancea, Liana: Nacionalista politika ..., 2011, i.m., 342-347. 


\begin{tabular}{|l|l|}
\hline kényszerközösség & szabadság, választható \\
\hline bizonytalanság & biztonság \\
\hline komoly, „sors” & lehetőség a játékra \\
\hline informális & formális \\
\hline időben változó & túlmutat az időn \\
\hline mindennapi & ünnepi (szimbolikus) \\
\hline „úton levés” (hontalanság) & „megérkezés” \\
\hline befelé (fontos) & kifelé (fontos) \\
\hline „folyamatos edzésben van” & örök, állandó \\
\hline adottság, ,van” & megérdemelt, „megszereztük”, „kaptuk”, \\
\hline kontextuális & stabil, „maradandó papír” \\
\hline régi & új \\
\hline szintekbe szerveződés & egysíkú, homogenizál \\
\hline
\end{tabular}

A kisebbségi magyar identitás továbbá kényszerközösségekben alakult ki és szilárdult meg, amelynek szoros velejárója a sorsszerüség képzete, a magárahagyatottság, a hontalanság megannyi mikro-tapasztalata. Ezzel szemben az új magyar állampolgárság az egyéneket szólította meg, ezáltal rést ütött a magárahagyatottság érzetén és a haza reményét csillantotta fel. Az anyaországi megszólíttatásra egyénileg adott válaszok egyfajta felszabadultsággal is járnak, a sors „komolyságát” felváltja a választás szabadsága. A korábbiakban csak kis közösségek tagjaként értelmezett, jobbára informális kötődések a nemzet tagjaként való formális továbblétezés lehetöségeként is érvényesülnek. Ez azt is jelenti, a magyar állampolgárság, mint formális, dokumentálható hovatartozás az időbeni stabilitás képzetét hordozza, mondhatni átnyúlik az időn, szemben a kisebbségi léthez kapcsolódó korlátozott időintervallummal. A kisebbségi identitásnak még az egyéni életidőn túlmutatóan is van egy kezdő nullpontja, Trianon, míg a magyar állampolgárság történelmi jóvátételként, az időt maga alá gyürve tételeződik. Míg Trianon az állampolgárok feje felett vándorló határok metaforája, addig az új állampolgárság a határok felett átvándorolt lehetőségként tételeződik. 
„Azt hittem én is, hogy formalitás lesz, aztán mégis, amikor ott volt az eskütétel, meg a szövege, meg az eskünek a szövege, meg a magyar himnusz, már úgy meghallgatni kiséröként, ugye, amikor édesanyám letette, azért más volt nekem. Azt hittem, hogy nem az lesz. Hát mondjuk ki, szétsírtuk magunkat anyuval, hogy valahogy más volt, nem tudom miért. De tudom, hogy nem fog ez... nem is tudom... tehát semmilyen formában, úgy gondolom, hogy most nem jöttünk másként ki a konzulátusról, de azért mégis. (...) Mert szerintem az csak bennünk van, hogy ha belegondolunk, akkor most igen, egy ilyen nagy közösségnek lettünk, vagy most másként lettünk annak a nagy közösségnek a tagjai.” (3. sz. interjú, Vajdaság)

Az új állampolgárság ugyan ,alanyi jogon” jár a nemzet tagjainak, de mégis mintha meg kellett volna „harcolni” érte: e harc maga a kisebbségi lét névtelen mindennapjai voltak, azok az adottságok, amelyben élni, folyamatos „edzésben lenni” kényszerült a kisebbségi ember. A névtelen mindennapokba azonban beékelődött egy közelmúltbeli dátum (2004. december 5.), amelyet az állampolgárság perspektívája sem feledtet: olyan eseményként tételeződik, amely folyamatosan visszairányítja a figyelmet a magyar-magyar kapcsolatokra és nem föltétlen pozitív kicsengésü egymásrautaltságra. Ezzel szemben az állampolgárság megszerzése maga az ünnep, amelyet szimbolikus kötelék-jelek ${ }^{43}$ kísérnek. Az ünnep másképpen kezdte strukturálni a kisebbségi ember tér-idő használatát, egyéni, új, visszatért időszámítást kezdett el, és ugyan az extravertáltság (például: utazások) lehetőségét veti fel pragmatikus szinten, érzelmi síkon viszont a bensőséges, meghitt „hazaérkezés”, „megérkezés” lehetőségével kecsegtet a megannyiszor megélt belső hontalanság állapotával szemben.

„Nagymamám kezébe kapta nemrég a magyar személyit, hát elsirta magát. Mert magyar időben született és neki az... nem fog ö már Záhonyig se menni 76 évesen soha többet, azon kivül, amikor egy eskütételre ugyebár kimentünk, kimentek... de neki az csak... és ott van szépen a kis ágya mellett, vitrinbe ki van téve.

43 A kötelék-jelek fogalma Goffmantól származik. Ld. Goffman, Erving: A hétköznapi élet szociálpszichológiája. Budapest, Gondolat, 1981. 352-426. 
És neki... reggel ránéz és azóta nem betegeskedik. Én esküszöm... egyszerüen... nyugodtabb, vidámabb... Nem, ezt komolyan mondom. Én otthon látom minden nap, és azóta boldogabb.” (6. sz. interjú, Kárpátalja)

A kisebbségi identitás részben a ,régi”, terület szerinti állampolgárságból származik: e kötődés megítélése a semleges és negatív megbélyegzettség tengelyén értelmeződik. Semleges értelemben a kisebbségi ember elismeri az állampolgársághoz tartozó jogok és kötelezettségek „klasszikus” halmazát (adó, törvények tisztelete), de narratívájukban ez az állampolgárság (és identitás) gyakran átcsúszik valamiféle hiánnyá, ezért gyakran negatívan is értelmeződik. E kontextusban a „régi állampolgárság” a hontalanság érzetének gyökere és következménye (pl. Szlovákiában), a korrupció melegágya (pl. Ukrajnában), a kiszolgáltatottság megtestesítője (például Vajdaságban) is. Az új, magyar állampolgárság e vonatkozásban valamilyen érzelmi többletet jelent, a régi állampolgárságot meghaladó ,tisztaság”, az igaz, őszinte kötődés, a „szabadság”, avagy a súlytalan, következmények nélküli játék metaforájává is válik.

„Egy közösségben vagyok azzal a tízmillió, vagy most már kilencmillió magyar állampolgárral, és ha én Magyarországon vagyok, és megállít a rendör, akkor én direkt a románt veszem elö, hogy a románt büntesse meg." (7. sz. interjú, Kolozsvár)

Ez nem jelenti ugyanakkor azt, hogy bizonyos gondolati sémákat ne lehetne átvinni az új magyar állampolgárságra is. Ha például Kárpátalján az állampolgárság a korrupció tételezésével függ össze, ebből az is következik, a magyar állampolgárságot is meg lehet szerezni e praxis által:

„Én a túloldalon, odaát, Magyarországon vettem föl az állampolgárságot, olyan személyekkel, aki megkapta az állampolgársági okiratát, és nem tudta, hogy mi van beleírva. És akkor ukránul kérdezi, hogy mi van ideírva? Egy! Kettö: Voltunk körü̈lbelül százhúszan, himnuszt körüllbelül hárman énekeltünk, vagy öten esetleg, nem többen, és az eskütétel szövegét is csak ímmel-ámmal, szájhúzogatva, néhányan esetleg, ha említették, 
vagy mondták. Tehát nekem nincsenek jó tapasztalataim. (...) Nem tudtak magyarul, persze. Lehet vásárolni papírokat, amivel igazolja a magyarságát, és itt tartunk." (5. sz. interjú, Beregszász)

A kisebbségi identitás elemei - mint korábban láthattuk egymásra szerveződnek, képlékenyek, sokszor bizonytalanok és viszonylagosak. A magyarországi politikai vagy mindennapi perspektívából használt címkék (,határon túli magyar”, „külhoni magyar”, „erdélyi magyar”, „vajdasági magyar”, „kárpátaljai magyar”, „felvidéki magyar”, de az „ukrán”, „román”, „szlovák”, „szerb” stb.) csak részlegesen rímelnek az érintettek önbesorolására, és túlzás lenne azt állítani, hogy e bélyegek között teljes lefedettség lenne. E címkék használata ugyanakkor kontextuális, és társadalmi rétegződéshez is kötött, és mindenképpen a külhoni magyar közösségek belső tagoltságáról árulkodik. Mindezzel szemben a magyar állampolgárság perspektívája homogenizál, a magyar nemzet - elviekben, formálisan egyenlő - részévé teszi e sokféleségben élő személyeket. E perspektíva a nemzeti, kisebbségi identitásdomborzatokra igyekszik ráhúzni az állampolgárságból eredeztethető egyenlőség eszmét. Ez által a kisebbségi lét felszámolására tett kísérletként is értelmezhetjük, a többségivé válás perspektíváját is felvillantja, miközben nyilvánvaló, hogy a kisebbségi identitáselemek felszámolása valójában önfelszámolás lenne. ${ }^{44}$

\section{Összegzés}

Tanulmányunk során megvizsgáltuk, hogy a nemzetközi szakirodalomban a kettős (többes) identitás szociológiai (nem normatív) vonatkozásai hogyan értelmeződnek. Azt találtuk, hogy függetlenül a többes állampolgárság jellegétől, az állampolgárság és identitás témakörei szorosan összefüggnek, annál is inkább, mert a felkínálkozó jogi lehetőségeket individuális döntésekkel lehet kitölteni. Így a szakirodalomból megismert, a kettős állampolgárság vonatkozásában tárgyalt flexibilitás és a hierarchiába rendeződés minden bizonnyal magyar viszonylatban is érvényes. Érvelésünk

44 Ez az ellentmondás köszön vissza közösségi szinten a diaszporizálódás veszélyének emlegetésekor. 
során tehát abból indultunk ki, hogy a magyar állampolgárság újfajta identitáselemeket is generál, azonban ezek betagozódnak a kisebbségi identitás szerkezetébe: lehetőségként ugyan jelen vannak, de nem írják teljes mértékben felül a korábbi viszonyulási módokat. Ebböl kifolyólag a magyar-magyar kölcsönös elöítélet-rendszer fennmarad, ám éppen ez az, ami majd tompítja a kettős állampolgárság esetleges negatív hatásait.

A magyar állampolgárság választása is individuális: ugyan nem posztnacionális értelemben, hanem a kisebbségi életfeltételek közösségi és egyéni meghaladásának lehetőségét hordozó értelemben. Posztnacionális értelemben ugyanis az identitás azt jelenti, hogy az egyének választhatják meg az országot, és nem az ország választja meg az egyéneket. ${ }^{45} \mathrm{~A}$ határon túli magyarok esetében viszont valójában az ország választotta meg az egyéneket (eddig a tradicionális állampolgárság logikájában mozgunk), de az egyének hozzájárulása, legitimációja is szükséges volt. E kontextusban könnyen belátható, hogy az anyaországhoz, a nemzethez kapcsolódó identitások és irányultságok erősödhetnek, és kérdés, mi lesz a helyi világokhoz és a szülőföldnek is helyet adó nemzetállamhoz való viszonyban. Mint jeleztük, e kérdésre erdélyi szakértők jobbára azt a negatív kicsengésű kommunitárius (közösségközpontú) választ adták, hogy ezen új jogi kötelékkel fennáll a diaszporizálódás veszélye, illetve a saját társadalom projekt megbukásának lehetősége.

Kvalitatív megközelítésünk, amely a magyar-magyar etnicizálódás mikroperspektíváját is figyelembe veszi, nem föltétlenül erösíti meg e kommunitárius vészforgatókönyvet. Feltételezhetjük ugyanis, hogy a mindennapi interakciók szintjén jelentős (egzisztenciális, társadalmi, politikai) változást nem fog eredményezni az állampolgárság, de az is igaz, hogy a mobilitási lehetőségek kiterjedése által, mindenképpen magában hordozza a (magyarországi) többségivé válás/utazás lehetőségét. Ad absurdum a kisebbségi identitás erősödésével és meghosszabbításával is járhat, hiszen a „többségivé utazni” (értsd: migrálni) - normál körülmények között - csak egy szükebb réteg számára lehet életstratégia, a „hátrahagyott” kisebbségi magyarok többsége szülőföldjén szeretne

${ }^{45}$ Dahlin, Eric C. - Hironaka, Ann: Dual Citizenship. In: Sociological Inquiry. 2008, 1. 54-73. 
maradni, és számbeli kisebbségüknél fogva az egymással szembeni szolidaritástudat is erősödhet. Az anyaország ugyan mentálisan közelebb kerül (de már eddig is elég közel volt a magyar nyelvü médiatér kiterjedésével), a saját kisebbségi világtól pedig ennek ellenére sem tud elszakadni. Magyarország mentális közelsége biztonságot is nyújthat, de ez nem jelenti a kisebbségi élethelyeztek, vagy akár az otthontalanság érzetének automatikus felszámolását.

Fókuszcsoport-beszélgetéseink elemzése során rávilágítottunk arra is, hogy az új magyar állampolgárság értelmezése, megélése sok szempontból kiteljesíti vagy felnyitja a kisebbségi élethelyzetek másfajta, gyakran pozitív megélésének lehetöségeit. A néha kritikus, néha euforikus új identitásformák kialakulásával párhuzamosan azonban azt is könnyü belátni, hogy az állampolgársághoz kapcsolódó pragmatikus hasznok mellett, az ünnepi, szimbolikus vonatkozások rutinizálódnak, banálissá válnak, ${ }^{46}$ beolvadnak majd a kisebbségi élethelyzetek mindennapjaiba.

A makropolitikai jóslatoktól eltekintve azonban azt leszürhetjük, hogy jelenlegi geopolitikai feltételek mellett éppen a határon túliak kisebbségi, illetve a magyarországiak többségi etnocentrizmusa lesz az, ami megakadályozza az új állampolgárságból elméletileg levezethető diaszporizálódást. A diaszporizálódás - ahogy azt többen is jelezték - reális kockázat, de azt gondolom, jelentős tényezők hatnak ez ellen, azaz a kisebbségi habituális világ fenntartásának irányába is. Elöször is a regionális kötöttségek és a nemzetállami szocializáció miatt az előítéletek rendszere, a magyar-magyar etnikai látószögre kiható társadalmi távolságok újratermelödnek határon túl és Magyarországon is. A kettős állampolgárság ennek következtében társadalmi szinten, de az egyéni interpretációk szintjén is, nem egyenlő állampolgárságokat fog eredményezni. Mindezt megtoldhatjuk azzal, hogy a határon túli magyarok már eleddig is intenzíven magyar médiatérben éltek, és mégsem távolodtak el saját politikai képviseletük fenntartásától. Ha ez a veszély fennállna, jóhiszemúen feltételezhetjük azt is, hogy a kisebbségi és többségi magyar politikusok felismernék e veszélyt. ${ }^{47}$ Vélhetően a többségi államoknak sem lenne közömbös a magyarok

\footnotetext{
${ }^{46}$ Vö. Billig, Michael: Banal Nationalism. SAGE Publications Inc., 1995

${ }^{47}$ Ilyen jelnek tekinthetjük az RMDSZ és FIDESZ 2014. évi paktumait is.
} 
intenzív elvándorlása, hiszen ez - a vélt esetleges rövidtávú érdekeik ellenére - számukra is veszteségekkel járna.

Az állampolgárság pragmatikus és szimbolikus haszonnal egyaránt jár, a kettős állampolgárok pedig megengedhetik maguknak majd a kontextuális és hierarchiába szervezett használatukat is, egyszersmind flexibilisebbé válik. A magyar állampolgárság kétségtelenül az otthon/haza, valamiféle bensöségesség érzetét hordozza, de ha valaki valóban migrálni kényszerül, szembesül a magyarországi mindennapokban továbbra is jelen lévő, nemzetállami hagyományokra visszavezethető mentalitással. Az állampolgárság alapjáraton nem tesz különbséget a polgárok között, de a mindennapi interakciókban románként/ukránként/szerbként/szlovákként avagy erdélyiként/kárpátaljaiként/vajdaságiként/felvidékiként

megkonstruált személyek, ha nem is másodrendü polgárok, de mindenképpen jövevényként, „másként”, „idegenként” lesznek kimondva, kimondatlanul - megbélyegezve. Vagy ha nem, az érintettek sok esetben így fogják érezni vagy besorolni önmagukat. Hasonló módon a kisebbségi etnicitás perspektívájából a többségi, azaz a „magyarországi” magyarok is a különbségteremtés áldozatai lesznek. A láthatatlan korlátok és ezáltal a kisebbségi „közösségek” vélhetően továbbélnek.

\section{IRODALOM}

Aleinikoff, T. Alexander - Klusmeyer, Douglas: Plural Nationality: Facing the Future in a Migratory World. In: Weiner, Myron - Russel Stanton, Sharon (szerk.): Demography and National Security. New York, Berghahn, 2001.

Arendt, Hannah: The Origins of Totalitarianism. Cleveland-New York, The World Publishing Company, Meridian Books, 1951.

Bárdi Nándor: Otthon és haza. Tanulmányok a romániai magyar kisebbségek történetéről. Csíkszereda, Pro Print, 2013. 
Bauböck, Rainer: Stakeholder Citizenship and Transnational Political Participation: A Normative Evaluation of External Voting. In: Fordham Law Review. 2007, 5, 2396-2447.

Bausinger, Hermann: A haza fogalma egy nyitott társadalomban. In: Regio. 1991, 4.

Bausinger, Hermann: Népi kultúra a technika korszakában. Budapest, Osiris, 1995.

Billig, Michael: Banal Nationalism. SAGE Publications Inc., 1995

Bloemraad, Irene: Who claims dual citizenship? The limits of postnationalism, the possibilities of transnationalism, and the persistence of traditional citizenship. In: International Migration Review. 2004, 38 (2).

Brubaker, Rogers: Nationalism Reframed: Nationhood and the National Question in the New Europe. Cambridge University Press, 1996.

Brubaker, Rogers: Csoportok nélküli etnicitás. In: Kántor Zoltán (szerk.): Szöveggyüjtemény a nemzeti kisebbségekröl. Budapest, Rejtjel. 2005.

Brubaker, Roger - Feischmidt Margit - Fox, Jon - Grancea, Liana: Nacionalista politika és hétköznapi etnicitás egy erdélyi városban. Budapest, L'Harmattan, 2011. 219-252.

Convay, Dennis - Potter, Robert B. - Bernard, Godfrey St.: Dual citizenship or dual identity? Does transnationalism' supplant 'nationalism' among returning Trinidadians? In: Global Networks. 2008, 4. 373-397.

Dahlin, Eric C. - Hironaka, Ann: Dual Citizenship. In: Sociological Inquiry. 2008, 1. 54-73.

Fox, Jonathan: Unpacking „Transnational Citizenship”. In: Annual Review of Political Science. 2005, 8.171-201. 
Goffman, Erving: A hétköznapi élet szociálpszichológiája. Budapest, Gondolat, 1981.

Gustafson, Per: Globalisation, multiculturalism and individualism: the Swedish debate on dual citizenship. In: Journal of Ethnic and Migration Studies. 2002, 3.

Hammar, Tomas: State, nation, and dual citizenship'. In: Brubaker, Robert (szerk.): Immigration and the Politics of Citizenship in Europe and North America. Lanham. MD, University Press of America. 1989.

Kasznár Veronika Katalin: Versengő nemzetfogalmak a kettős állampolgárságról szóló 2004-2005-ös publicisztikai vitákban. In: Feischmidt Margit és tsai: Nemzet a mindennapokban. $A z$ újnacionalizmus populáris kultúrája. Budapest, MTA TK L'Harmattan, 2014, 209-248.

Kiss Tamás: Nemzetdiskurzusok hálójában. Az állampolgárságpolitika, mint a magyar nemzetre vonatkozó klasszifikációs küzdelem epizódja és eszköze. In: Magyar Kisebbség. 2013, 3-4, 7-95.

Kiss Tamás - Barna Gergö: Erdélyi magyarok és románok a politikai térben. Cluj Napoca, Institutul Pentru Studierea Problemelor Minoritatilor Nationale, 2013.

Martin, David A. - Aleinikoff, T. Alexander: Double Ties. In: Foreign Policy. 2002. 133:80-81.

Ong, Aihwa: Flexible Citizenship. The Cultural Logics of Transnationality. Duke University Press, 1999.

Papp Z. Attila: Beszédböl világ. Elemzések, adatok amerikai magyarokról. Budapest, Magyar Külügyi Intézet, 2008.

Pogonyi Szabolcs: Dual citizenship and sovereignity. In: Nationalities Paper. 2011, Vol. 39., 5. 685-704. 
Rubio-Marin, Ruth: Transnational Politics and the Democratic Nation-State: Normative Challenges of Expatriate Voting and nationality Retention of Emigrants. In: New York University Law Review. 2006, 81. 136.

Salat Levente: A politikai közösség kérdése a többség-kisebbség viszonyának a nézőpontjából. In: Hatos Pál - Novák Attila (szerk.): Kisebbség és többség között. A magyar és a zsidó/izraeli etnikai és kulturális tapasztalatok az elmúlt századokban. Budapest, L'Harmattan, 2013. 213-258.

Salat Levente: A könnyített honosítás látható és várható következményeiről. Válaszok a Magyar Kisebbség kérdéseire. In: Magyar Kisebbség. 2013, 3-4.

Spiro, Peter J.: Dual citizenship as human right. I • In: Con. 2010, 1.

Spiro, Peter J.: Accepting (and Protecting) Dual Citizenhip for Transborder Minorities. In: Bauböck, R. (szerk..): Dual Citizenship for Transborder Minorities? How To Respond For The HunagrianSlovak Tip-For-Tat? EUI Working Papers, RSCAS, 2010, 75.

Stachel, Peter: Identitás. A kortárs társadalom- és kultúratudományok egy központi fogalmának genezise, inflálódása és problémái. In: Regio. 2007, 4. 3-33.

Szabó Marcel: A többes állampolgárság - új nemzetközi és uniós perspektívák felé? In: Állam és Jogtudomány. 2013, 1-2.

Thomassen, Bjorn: The uses and meaning of liminality. In: International Political Anthropology. 2009, 2. 5-27.

Veres Valér - Papp Z. Attila (szerk.): Szociológiai mintázatok. Erdélyi magyarok a Kárpát Panel vizsgálatai alapján. Kolozsvár, Nemzeti Kisebbségkutató Intézet - Max Weber Társadalomkutatásért Alapítvány, 2012. 
Vertovec, Steven: Super-diversity and its implications. In: Ethnic and Racial Studies. 2007, 6. 1024-1054. 